\title{
Measuring the Effect of Use Web 2.0 Technology on Saudi Students' Motivation to Learn in a Blended Learning Environment
}

\author{
Sarah M.Bin-jomman, Mona Al-Khattabi \\ Department of Information Systems \\ College of computer and information sciences \\ Al-Imam Muhammad Ibn Saud Islamic University \\ Riyadh, Saudi Arabia
}

\begin{abstract}
Students' motivation to learn is the goal of the educational process around the world. There is a close link between learning outcomes and students' motivation to learn. Thus, the success of blended learning in Saudi higher education depends on not only using different teaching methods and massive expenditures on technology but also on students' motivation to learn. The main objective of this study is to measure the effect of using the Web 2.0 technology on students' motivation to learn in a blended learning environment through their attention, relevance, confidence, satisfaction inside in this environment. This study used a randomized experimental research design to examine differences in student's motivation based on their use of Web 2.0 tools in a blended environment in the Computer Science at Al-Imam Muhammad Ibn Saud Islamic University (IMSIU). This study adopted Keller's ARCS model of motivation to develop a comprehensive framework of factors that affect the use of Web 2.0 tools in blended learning environment. A questionnaire was conducted to collect data from students. Throughout our investigation, we found that there was a statistically significant difference at the level of 0.05 in overall student motivation between the experimental and control groups resulting from the using Web 2.0 tools technology. Moreover, students using Web 2.0 tools were found to exhibit a statistically significant higher degree of motivation. The results of this study can help decision makers readjust the learning strategy by realizing the importance of using Web 2.0 tools as the main platform in Saudi higher education.
\end{abstract} model

Keywords-Web2.0 tools; blended learning; motivation; ARCS

\section{INTRODUCTION}

The use of technology has become a necessity and a trend in all countries of the world in various sectors. In education sector technology and the internet have changed the concept of the traditional classroom, which in the past depended on the students and the teachers being within the boundaries of the university classrooms. E-learning (distance learning) made educational process effective and unique by giving students the opportunity to create a new style of learning environment [1]. Despite the benefits of e-learning, it lacks some matters such as a student's sense of isolation outside the framework of the traditional learning community [2]. Then generate the concept of blended learning, which fills the weakness of online learning because it serves as a bridge constituting a balance between the use of technology (such as computer, learning management system, e-mail) and traditional learning, which based on face-to-face meetings, to form integrated educational environments for students to create a meaningful educational community. The main objective of blended learning is to improve the ways and methods of instruction, increase flexibility and reduce time restrictions so a student can choose when and where to learn. According to [3], blended learning created motivation to learn within that environment since it fits the student's needs and circumstances.

Learners may face challenges in building technical skills and self-control in blended learning environment. According to the theory of learning by [3] "learning is socially situated within community of practice". Thus, learning requires social interaction through the integration of the Web 2.0 technologies as the main platform in a blended learning environment. Dealing with learning methods will change completely and education will become not only a way to get a certificate awarded to a student for gaining employment but also a motivation for learning to build an effective strategy that based on a learner-centered approach.

The goal of education is enhanced quality of education for everyone all over the world. Currently, students do not use wiki, blogs, social networks and other tools effectively in education. Web 2.0 is not just technology but considered as a dynamic social platform that changed the concept of people when using the web. It solves the problems by allowing people to share information on the Internet. [4] investigated the benefits of social networks such as Facebook and Twitter and his found many benefits such as facilitating the participation of content, improving discussions among students, enhancing intimacy between students, and meeting people who have the same interests. The variety of Web 2.0 technologies are also a benefit because they allow for a degree of user choice when deciding on the best method of learning [18]. There is lack of integration of Web 2.0 technology with universities in Saudi Arabia. This paper aims to examine the effect of the Web 2.0 technology on students' motivation to learn in a blended learning environment. To help decision makers realize the relationship between utilizing the Web 2.0 
technology and students' motivation to learn to readjust an educational process strategy in Saudi Arabia.

The remainder of this paper is structured as follows: Section II explores the basic concepts of blended learning. Section III describe categories of blended learning environment. Section IV investigates the importance of use web 2.0 in education sector while Section V explains motivation to learn as the critical factor in education process. Finally, research method and model to measure the effect of using the Web 2.0 technology on students' motivation to learn in a blended learning environment are presented in Section VI. Research results are discussed in Section VII. Finally, Section VIII concludes the paper.

\section{BASIC CONCEPTS OF BLENDED LEARNING}

In the past, traditional learning and online learning were separate from each other because of the difference in teaching methods. Innovations in technology and investments in education facilitated human interactions synchronously and asynchronously to integrate traditional learning into an online learning environment to constitute a blended learning concept [5]. There was no agreed standard definition for blended learning among academics and practitioners. Some researchers referred to blended learning a "buzzword", but many agree that a blended learning system refers to a combination of traditional face-to-face classroom instruction and any of a wide variety of computer-mediated instruction, including Web 2.0 [6]-[8]. The author in [9] defined blended learning as " $a$ system, which focuses on optimizing achievement of learning objectives, by applying the 'right' learning technologies, to match the 'right' personal learning style, to transfer the 'right' skills, to the 'right' person, at the 'right' time". Furthermore, blended learning represents as "the organic integration of thoughtfully selected and complementary faceto-face and online approaches and technologies" [10].

\section{CATEGORIES OF BLENDED LEARNING ENVIRONMENT}

Blended learning represents the convergence of digitally distributed enabled by ubiquitous broadband internet connectivity using a combination of synchronous and asynchronous programs and applications and the traditional classroom-learning environment. Blended environments have the potential for four dimensional integrations along the following continuums: (a) space (physical/face-to-face vs. distributed), (b) time (live/synchronous vs. asynchronous), (c) fidelity (rich/all senses vs. text only), and (d) humanness (high human/no machine vs. no human/high machine [11]. For example, an online course can add synchronous distributed interactions to the distributed space using live chats or webinars. Fidelity can be managed using multimedia presentation, videos, or guest speakers while humanness may be enhanced using virtual communities or group messaging technologies. As these four dimensions are used to create new solutions, blended instruction will evolve. Moreover, [6] argues that the learner has the opportunity to gain learning in an environment that combines face-to-face learning and online learning, and he suggests that it is not sufficient for the institution to have fully online learning that is largely separate from traditional learning. He classified blend into three categories. Table I summarizes the main differences between these categories.

Furthermore, Studies have shown that blended learning increased attention, relevance and satisfaction with online classes by developing their capacity for reflection. Multiple modes of delivery for course content, using a wiki, blog, social media and webinar, improved the learning process and improved participants' grades [12], [13]. In [14], the author conducted a comparison of a traditional and blended course in undergraduate Management. Blended class participants more easily formed social bonds with classmates, felt safe to communicate thoughts and ideas freely, and expressed a sense coherence with group goals. According to [15], blended courses create a sense of significant social learning compared with courses through online learning or traditional learning alone. They mentioned that blended learning should have the following three characteristics:

- The learner becomes the center of the learning process rather than the instructor.

- There is improved interaction between students, between student and content, and between student and instructor.

- There is an integration of formative (monitor student learning) and summative assessment (evaluate student learning) mechanics of the student and the teacher.

TABLE I. BLENDED LEARNING MAIN CATEGORIES

\begin{tabular}{|l|l|l|}
\hline \multirow{2}{*}{ Main categories } & \multicolumn{2}{|l|}{ Description } \\
\cline { 2 - 3 } Enabling blend & $\begin{array}{l}\text { Definition } \\
\text { Provide the same } \\
\text { opportunities or learning } \\
\text { experience to learners by } \\
\text { selecting their courses in } \\
\text { different modes. }\end{array}$ & $\begin{array}{l}\text { Face-to-face and } \\
\text { online. }\end{array}$ \\
\hline Enhancing blend & $\begin{array}{l}\text { Allow adding of changes to } \\
\text { the pedagogy but not } \\
\text { fundamental change to the } \\
\text { method of teaching. }\end{array}$ & $\begin{array}{l}\text { In traditional face-to- } \\
\text { face, including } \\
\text { supplementary online } \\
\text { resources for courses. }\end{array}$ \\
\hline $\begin{array}{l}\text { Transformation } \\
\text { blend }\end{array}$ & $\begin{array}{l}\text { Provide a fundamental change } \\
\text { in the method of teaching by } \\
\text { using new modern } \\
\text { technological approaches in } \\
\text { teaching. }\end{array}$ & $\begin{array}{l}\text { Transform the model } \\
\text { that depended receives } \\
\text { information to model } \\
\text { that construct } \\
\text { knowledge. }\end{array}$ \\
\hline
\end{tabular}

Learners may face challenges in building technical skills and self-control in blended learning environment. Thus, learning requires social interaction through the integration of the Web 2.0 technologies as the main platform in a blended learning environment [3]. Dealing with learning methods will change completely and education will become not only a way to get a certificate awarded to a student for gaining employment but also a motivation for learning to build an effective strategy that based on a learner-centered approach. 
They offer the best opportunity to use learning settings based on student-centered strategies [15].

\section{Web2.0 TeChNOLOGY as Platform In EduCATion}

The goal of education is enhanced quality of education for everyone all over the world. Web 2.0 refer to group of webbased technology that promote user-generated content, sharing information and users' capabilities communication [16]. It has many tools and services, such as blogs, wikis, social networks, Ajax, RSS, tagging, etc. Dale Dougherty, a vice president of O'Reilly Media Inc. in a conference, which discussed the future of the web, first appeared the term web 2.0 in 2004 [17].

The authors in [18] indicated four-dimensional of web 2.0 that integration along the following continuums: interactivity, real-time user control, social participation (sharing), and usergenerated content. These four-dimensional promote student participation and engagement, which are essential to the instructional learning dynamic. For example, Twitter are environment depends on the generation of content and collaboration user between user which mean sharing opinions, posting, comment, assessment, discussions, and exchange of experiences. Web2.0 technology considers personalization to the learner by matching learning preferences or needs and tracking behavior to the specific interests of different learners it is not just technology but is considered a dynamic social platform that changed the concept of people when using the web [19].

Faculty and instructional designers are increasingly expected to incorporate Web 2.0 technologies and applications into their teaching. Educators sense a sort of "moral panic" in higher education to change teaching and learning practices to meet the demands of the online generation [18]. The trend toward technology convergence was consistent with the core educational principles that academic outcomes are improved by increasing student engagement and improved social interactions, both learner-learner and learner-instructor interactions. The author in [20] reported that learner-content interactions are more important indicators of learner outcomes than learner-instructor or learner-learner interactions. Moreover, it solves the problems by allowing people to share or understand information via the Internet. Web 2.0 applications for education were designed to improve student engagement using all three types of interactions. That confirmed the importance of Web 2.0 by provides tools that support the teaching and learning process, which helps students improve their performance not only in boundary universities but also from these technologies.

\section{Motivation To Learn}

Students' motivation to learn is the goal of the educational process in new methods of learning, such as blended learning. There is a close link between learning outcomes and students' motivation to learn. Motivation considered as "a process that requires students to perform physical or mental activities for achieving their goals" [21]. It is a critical element for learning and accounts for between $16 \%$ and $38 \%$ of the variance in studies on university student learning variance [22], [23].
Motivation remains the critical factor in learning despite developments in pedagogy and drastically improved educational technologies. As such, studies to improve teaching and learning based on technology adoption should consider the principles of motivation and their application to technology adoption. There are two mainly type of motivation: intrinsic and extrinsic. Intrinsic motivations come from inside the individual. Thus, inner satisfaction can drive a student to learn and achieve success. Extrinsic motivations come from outside the individual, such as a student's success in learning by obtaining external rewards [24]. There are many studies showed that the students' intrinsic and extrinsic motivations have a significant impact on the educational process. Especially, collaborative-based learning can be an effective way for the learner to be the center of the learning process. Learning environments should foster intrinsic learning motivation.

\section{A. Keller's Model of Motivational Design ARCS Model}

Enhancing student learning motivation and participation is crucial for the teaching and learning of new knowledge or skills since motivation would affect how instructors and students interact with learning materials. In the era of Web 2.0 could be a potentially novel method to engage instructors and students in meaningful teaching and learning activities. The author [25] developed the ARCS model which stands of (attention, relevance, confidence and satisfaction) model to understand, predict, and develop strategies for improving motivation to learn.

ACRS model is based on expectancy - value theory of motivation which develops motivational strategy [26]. This theory has two components namely the student can expect to succeed in the learning and the value of learning to the learner. Table II summarizes the characteristics of the ARCS model. The ARCS model synthesizes behavioral, cognitive, and effective learning theories into a single unified framework for examining motivation and academic success. Keller's ARCS Model of Motivational Design suggests that student motivation may be affected by to improving the motivational appeal of instruction [27].

TABLE II. CHARACTERISTICS OF THE ARCS MOdEL

\begin{tabular}{|l|l|}
\hline $\begin{array}{l}\text { Characteristics of } \\
\text { the ARCS Model }\end{array}$ & Definition \\
\hline Attention & $\begin{array}{l}\text { Educators must have the student's fairly constant } \\
\text { attention. }\end{array}$ \\
\hline Relevance & $\begin{array}{l}\text { How closely the course content connects each } \\
\text { student's personal experiences, hopes, dreams, or } \\
\text { desires. }\end{array}$ \\
\hline Confidence & $\begin{array}{l}\text { Function of establishing student's positive } \\
\text { expectation for success. }\end{array}$ \\
\hline Satisfaction & $\begin{array}{l}\text { Positive feelings associated with the relationship } \\
\text { between the amount of effort expended and one's } \\
\text { accomplishments and learning experiences. }\end{array}$ \\
\hline
\end{tabular}




\section{METHODOLOGY AND HYPOTHESES}

The aim of this study is to investigate the effect of using Web 2.0 technology to motivate students to learn within a blended learning environment. This study adopted ARCS model in order to develop a comprehensive framework of factors that effect of use Web 2.0 in blended learning environment. The study uses an experimental research design with a control group and an experimental group. This research design is used to fulfill the objective of gauging the variation in a phenomenon (Web 2.0 technology), as well as measure changes in outcomes (levels of learning motivation). The control group is taught using traditional learning without integrating Web 2.0 tools. The experiment group is taught using traditional learning with integrated Web 2.0 tools.

\section{A. Hypotheses of the Study}

Following hypotheses were constructed to examine the effect the Web 2.0 technology in blended learning on students' motivation to learn in Saudi higher education:

$\mathbf{H}_{\mathbf{0}}$ : The student that using Web 2.0 tools in the blended environment will no perceive positive effect on their motivation.

$\mathbf{H}_{1}$ : The student that using Web 2.0 tools in the blended environment will perceive positive effect on their motivation.

\section{B. Sampling Procedure}

Sampling refers to the process of selecting a sample as a small portion or subset of a defined population [28]. The purpose of this study was to make use of a sample to generalize the findings in a particular population about how Web 2.0 technology tools enhance the learning motivation of students in higher education. Thus, the sample for this study is mainly based on simple random sampling. The control group and experiment group were selected randomly. This type of sample offers high generalizability of findings [28]. The sample population for this study was primarily on female students in the Computer Science at Imam Mohammad Ibn Saud Islamic University (IMSIU) during the second semester 2018. The study was used a convenience sample of 60 students assigned to two groups. Group 1 consisted of 30 students was attended a class that adopted Web 2.0 techniques. Group 2 consisted of 30 students was attended a class without using Web 2.0 techniques. This study focused on the three Web 2.0 tools listed in Table III since they are among the most widely used and recognized by students for education [29].

TABLE III. Web2.0 TOOLS USAGE AND PARTICIPANTS NUMBER IN EXPERIMENTAL GROUP

\begin{tabular}{|l|l|}
\hline Web 2.0 Tools & Participants Number \\
\hline Social Networks & 10 \\
Blog & 10 \\
Wiki & 10 \\
Total & 30 \\
\hline
\end{tabular}

TABLE IV. MEASURMENT SCALE ITEMS FOR STUdENTS Motivation

\begin{tabular}{|c|c|c|}
\hline Factors & Measurement Items & References \\
\hline \multirow{7}{*}{ : } & $\begin{array}{l}\text { 1. There was something interesting at the } \\
\text { beginning of this course that got my } \\
\text { attention. }\end{array}$ & \multirow{7}{*}{ [30] } \\
\hline & These materials are eye-catching. & \\
\hline & $\begin{array}{l}\text { 3. This course is so abstract that it was } \\
\text { hard to keep my attention. }\end{array}$ & \\
\hline & $\begin{array}{l}\text { 4. This course has things that stimulated } \\
\text { my curiosity. }\end{array}$ & \\
\hline & $\begin{array}{l}\text { 5. The amount of repetition in this course } \\
\text { caused me to get bored sometimes. }\end{array}$ & \\
\hline & $\begin{array}{l}\text { 6. I learned some things that were } \\
\text { surprising or unexpected }\end{array}$ & \\
\hline & $\begin{array}{l}\text { 7. The variety of exercises, illustrations, } \\
\text { etc., helped keep my attention on the } \\
\text { course. }\end{array}$ & \\
\hline Factors & Measurement Items & References \\
\hline \multirow{8}{*}{ 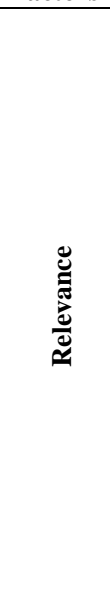 } & $\begin{array}{l}\text { 1. It is clear to me how the content of this } \\
\text { material is related to things I already } \\
\text { know. }\end{array}$ & \multirow{8}{*}{ [30] } \\
\hline & $\begin{array}{l}\text { 2. There were examples that showed me } \\
\text { how this material could be important to } \\
\text { some people. }\end{array}$ & \\
\hline & $\begin{array}{l}\text { 3. Completing this course successfully } \\
\text { was important to me. }\end{array}$ & \\
\hline & $\begin{array}{l}\text { 4. The content of this material is relevant } \\
\text { to my interests. }\end{array}$ & \\
\hline & $\begin{array}{l}\text { 5. There are explanations or examples of } \\
\text { how people use the knowledge in this } \\
\text { course. }\end{array}$ & \\
\hline & $\begin{array}{l}\text { 6. This course was not relevant to my } \\
\text { needs because I already knew most of } \\
\text { it. }\end{array}$ & \\
\hline & $\begin{array}{l}\text { 7. I could relate the content of this course } \\
\text { to things I have seen, done, or thought } \\
\text { about in my own life. }\end{array}$ & \\
\hline & $\begin{array}{l}\text { 8. The content of this course will be } \\
\text { useful to me. }\end{array}$ & \\
\hline Factors & Measurement Items & References \\
\hline \multirow{8}{*}{ ن⿺辶ِ } & $\begin{array}{l}\text { 1. When I first looked at this course, I had } \\
\text { the impression that it would be easy for } \\
\text { me }\end{array}$ & \multirow{8}{*}{ [30] } \\
\hline & $\begin{array}{l}\text { 2. This material was more difficult to } \\
\text { understand than I would like for it to } \\
\text { be. }\end{array}$ & \\
\hline & $\begin{array}{l}\text { 3. After reading the introductory } \\
\text { information, I felt confident that I knew } \\
\text { what I was supposed to learn from this } \\
\text { course. }\end{array}$ & \\
\hline & $\begin{array}{ll}\text { 4. } & \text { As I worked on this course, I was } \\
\text { confident that I could learn the content. }\end{array}$ & \\
\hline & $\begin{array}{ll}5 . & \text { The exercises in this course were too } \\
\text { difficult. }\end{array}$ & \\
\hline & $\begin{array}{l}\text { 6. After working on this course for a } \\
\text { while, I was confident that I would be } \\
\text { able to pass a test on it }\end{array}$ & \\
\hline & $\begin{array}{l}\text { 7. I could not really understand quite a bit } \\
\text { of the material in this course. }\end{array}$ & \\
\hline & $\begin{array}{l}\text { 8. The good organization of the content } \\
\text { helped me be confident that I would } \\
\text { learn this material. }\end{array}$ & \\
\hline Factors & Measurement Items & References \\
\hline \multirow{6}{*}{ : } & $\begin{array}{l}\text { 1. Completing the exercises in this course } \\
\text { gave me a satisfying feeling of } \\
\text { accomplishment. }\end{array}$ & \multirow{6}{*}{ [30] } \\
\hline & $\begin{array}{l}\text { 2. I enjoyed this course so much that I } \\
\text { would like to know more about this } \\
\text { topic. }\end{array}$ & \\
\hline & 3. $\quad$ I really enjoyed studying this course. & \\
\hline & $\begin{array}{l}\text { The wording of feedback after the } \\
\text { exercises, or of other comments in this } \\
\text { course, helped me feel rewarded for my } \\
\text { effort }\end{array}$ & \\
\hline & $\begin{array}{l}\text { I felt good to successfully complete this } \\
\text { course. }\end{array}$ & \\
\hline & $\begin{array}{l}\text { It was a pleasure to work on such a } \\
\text { well-designed course. }\end{array}$ & \\
\hline
\end{tabular}




\section{Data Collection and Instrumentation}

The authors used a questionnaire to collect the participants' perspectives about motivation to learn with and without using Web 2.0 tools in a blended course in Saudi higher education. This questionnaire designed according to Keller's ARCS model. This model focuses on measuring the effect of use web 2.0 technologies on students' motivation to learn in a blended learning environment. Five-point Likert scale used to determine the participants' perspectives for the level of agreementldisagreement expressed by them on each item, in which, 1 = strongly disagree, $2=$ disagree, $3=$ neutral, $4=$ agree, and $5=$ strongly agree. This study was used the Instructional Materials Motivation Survey (IMMS), a 36-item situational measure of motivation based on the ARCS model [30]. The IMMS measures all four ARCS Factors: attention, relevance, confidence, and satisfaction. The IMMS was selected to evaluate whether the blended-learning experience induces attention, relevance, confidence and satisfaction, and measures students' motivation levels. Some items were slightly modified and other items were dropped for a total of 29 items in this study. Table IV illustrates the measurement scale items for student motivation.

\section{DATA ANALYSIS AND RESULTS}

Cronbach's coefficient alpha (CA) is examined to measure coefficient of stability and Pearson correlation coefficient to measure internal consistency. The value of alpha coefficient should be greater than the threshold value of 0.70 to be accepted [28]. The results of the reliability test for the Factors are likely to be accepted because greater than 0.70. As shown in the Table $\mathrm{V}$ the alpha coefficients for the Factors ranged from 0.70 to 0.88 . Thus, it confirmed that all items of respondents' answers in this study were consistency and stability.

TABLE V. RELIABILITY STATISTICS

\begin{tabular}{|l|c|c|}
\hline Factors & No. of items & Cronbach's alpha \\
\hline Attention & 7 & 0.70 \\
\hline Relevance & 8 & 0.71 \\
\hline Confidence & 8 & 0.78 \\
\hline Satisfaction & 6 & 0.76 \\
\hline Overall & 29 & 0.88 \\
\hline
\end{tabular}

The data values of this study were normally distribution. The independent samples t-test was made to determine the difference between the students in the use Web 2.0 and those without using Web 2.0 technology. The groups were compared with respect to overall student motivation factors: attention, relevance, confidence and satisfaction. This analysis is appropriate to the aim of this study, thus we need to compare the means of two groups, and especially appropriate as the analysis for the posttest-only two-group randomized experimental designs.

\section{A. Attention Analysis}

The result of analyzing the data by using t-test formula shows that there is a significance increase in students' attention after they use web 2.0 technologies. Table VI indicates that the mean of the control group, the group do not use web2.0 tools (24.10), and the mean of experimental group, the group use web 2.0 tools (score is 25.87), the standard devotion of the control group, the group do not use web 2.0 tools is 2.67 and the standard devotion of experimental group, the group use web 2.0 is 2.83 . This mean that there is increase in mean of experimental group, the group use web 2.0 tools in attention factor. The result has shown the t- value at a degree of significance is 0.016 .

\section{B. Relevance Analysis}

The result of analyzing the data by using t-test formula shows that there is a significance increase in students' relevance after they use web 2.0 technologies. Table VI indicates that the mean of the control group, the group do not use web 2.0 tools is (28.63), and the mean score of experimental group, the group use web 2.0 tools score is (31.50) the standard devotion of the control group, the group do not use web2.0 tools is (4.33) and the standard devotion of experimental group, the group use web 2.0 tools is (3.99). This mean that there is increasing in mean of experimental group, the group use web 2.0 tools in relevance factor. The result has shown the $t-$ value at a degree of significance is $(0.010)$.

\section{Confidence Analysis}

The result of analyzing the data by using t-test formula shows that there is a significance increase in students' confidence after they use web 2.0 technologies. Table VI indicates that the mean of the control group, the group do not use web2.0 tools is (27.17), and the mean score of experimental group, the group use web 2.0 score is (29.23) the standard devotion of the control group, the group do not use web2.0 tools is (2.84) and the standard devotion of experimental group, the group use web 2.0 tools is (4.05). This mean that there is increasing in mean of experimental group, the group use web 2.0 tools in confidence factor. The result has shown the t- value at a degree of significance is (0.026).

\section{Satisfaction Analysis}

The result of analyzing the data by using t-test formula shows that there is a significance increase in students' Satisfaction after they use web 2.0 technologies. Table VI indicates that the mean of the control group, the group do not use web2.0 is (22.50), and the mean score of experimental group, the group use web 2.0 tools score is (26.90) the standard devotion of the control group, the group do not use web.20. is (3.89) and the standard devotion of experimental group, the group use web 2.0 tools is (3.56). This mean that there is increasing in mean of experimental group, the group use web 2.0 tools in confidence factor. The result has shown the $\mathrm{t}-$ value at a degree of significance is (0.000).

According to the results of four factors attention, relevance, confidence and satisfaction, the values of t-test were significant at the $0.05,0.01$ levels in each dimension attention, relevance, confidence and satisfaction. This indicates that there are statistically significant differences 
concerning these motivations of students that using Web 2.0 tools accordance with the differences in the groups in favor with Web 2.0 technology (experimental group). This result shows that there was a greater increase in motivation scores for the experimental group than for the control group. From this, we can conclude that using Web 2.0 technology affect students' motivation to learn in a blended learning environment.

\section{E. Hypotheses Testing Result}

There is significant difference in motivation, as measured by mean IMMS score, between a sample of students using Web 2.0 tools in a blended environment (experimental group) and a control group. To test the hypotheses, t-tests and p-value analysis tests were used to explore the motivation of students using Web 2.0 tools in a blended environment between the control and experimental groups. We found that there was a statistically significant difference at the level of 0.05 in overall student motivation between the experimental and control groups resulting from the using Web 2.0 tools technology. Moreover, students who using Web 2.0 tools technology were found to exhibit a statistically significant higher degree of motivation. Thus, the alternative hypothesis $\left(\mathrm{H}_{1}\right)$ was acceptable.

\section{CONCLUSION AND IMPLICATIONS OF THE STUDY}

This study tries to provide the best ways to deliver instruction methods and learning in Saudi higher education for the use of a blended learning environment. It aims to contribute to improving the educational process that measures the effect of using Web 2.0 technologies, including blogs, wikis, and other social networks, on motivation to learn inside blended learning. Essentially, the success of blended learning in Saudi higher education depends not only on using different teaching methods and massive expenditures on technology but also on students' motivation to learn, which reflects their creativity, exploration, and performance improvement and satisfaction. Our study found that there are statistically significant differences concerning these motivations of students using web 2.0 tools accordance with the differences in favor with web 2.0.

TABLE VI. T- TEST ANALYSIS

\begin{tabular}{|c|c|c|c|c|c|c|c|}
\hline 2 & Groups & Mean & $\mathbf{N}$ & Std. Deviation & t- value & df & $\mathbf{P}=$ Sig. \\
\hline \multirow{2}{*}{ Attention } & Without Web 2.0 & 24.10 & 30 & 2.67 & & & \\
\hline & With Web 2.0 & 25.87 & 30 & 2.83 & 2.89 & 58 & $0.016^{*}$ \\
\hline \multirow{2}{*}{ Relevance } & Without Web 2.0 & 28.63 & 30 & 4.33 & & & \\
\hline & With Web 2.0 & 31.50 & 30 & 3.99 & 2.665 & 58 & $0.010^{*}$ \\
\hline \multirow{2}{*}{ Confidence } & Without Web 2.0 & 27.17 & 30 & 2.84 & & & \\
\hline & With Web 2.0 & 29.23 & 30 & 4.05 & 2.288 & 58 & $0.026^{*}$ \\
\hline \multirow{2}{*}{ Satisfaction } & Without Web 2.0 & 22.50 & 30 & 3.89 & & & \\
\hline & With Web 2.0 & 26.90 & 30 & 3.56 & 4.571 & 58 & $0.000^{* *}$ \\
\hline \multirow{2}{*}{ Overall } & Without Web 2.0 & $0 \quad 102.4$ & 30 & 11.03 & & & \\
\hline & With Web 2.0 & $0 \quad 113.5$ & 30 & 10.53 & 3.987 & 58 & $0.000^{* *}$ \\
\hline
\end{tabular}


Students' motivation to learn is the goal of the educational process in new methods of learning, such as blended learning. There is a close link between learning outcomes and students' motivation to learn. Thus, the Web 2.0 technologies should be integrated into educational process. Web 2.0 technology to enrich teaching environments and they give creative and practical ideas to teachers on the use of these tools in Teaching. Thus, Web 2.0 technology encourages students to not only view and experience information on the Internet, but to also create and share their knowledge and opinions. In this sense, the overall purpose of this research was to investigate potential of using different Web 2.0 tools in blended learning as well as their advantage.

This study provides the following significant implications:

- The ARCS model is used in this study in order to measure the effect of using the Web2.0 technology on students' motivation to learn. After applying the experiment to two samples as an independent samples t-test, the result shows a positive effect of using tools on students to learn. Thus, Academics or educator may inspire to acquaint on other models that used in the blended learning to enhance motivation to learn.

- The finding can help study can help decision makers readjust the learning strategy by realizing the importance of using Web 2.0 as the main platform in Saudi higher education.

Further research could focus not only on whether blended coursework and Web 2.0 technology in general impacted student motivation, but on what types of this technology specifically had the strongest impact on motivation. The limitation of this study was conducted Keller's model of motivational design ARCS Model on small sample sizes. Thus, the results might change when applying ARCS model on bigger sample sizes.

\section{REFERENCES}

[1] U.S. Department of Education, Office of Innovation and Improvement, "Evaluating Online Learning: Challenges and Strategies for Success", Washington, D.C.: Education Publications Center, 2008.

[2] C. Clement, and K. Jones, "Blended Learning vs. Traditional Classroom Settings: Assessing Effectiveness and Student Perceptions in an MBA Accounting Course", Journal of Educators Online, vol. 4, no. 1, pp. 1$15,2007$.

[3] J. Lave, and E. Wenger, Situated learning. Cambridge [England]: Cambridge University Press, 1991.

[4] S. Abram, "Web 2.0, Library 2.0, and Librarian 2.0: Preparing for the 2.0 World". Library and Information Services in Astronomy, vol. 377, pp.161-167, 2007.

[5] J. Confrey, "How Compatible are Radical Constructivism, Sociocultural Approaches, and Social Constructivism?" in Constructivism in Education, Steffe LP and Gale,J Ed., ),Hover: UK, 1995.

[6] R. Graham, "Blended learning systems: Definition, current trends, and future directions," In The Handbook of Blended Learning: Global Perspectives, Local Designs. J.Curtis ,R. Graham, ,Ed., San Francisco, CA: Pfeiffer Publishing,2006, pp. 1-32.

[7] E.Rooney, "Blending learning opportunities to enhance educational programming and meetings", Association Management, vol.55, no,5 ,pp.26-32, 2003.

[8] J. Young, "Hybrid teaching seeks to end the divide between traditional and online instruction", Chronicle of Higher Education, vol. 35, no. 2, pp.33-34, 2002.
[9] C. Reed \& H. Singh, "Getting the best of both world", Training Strategies for Tomorrow, vol.16, no .4, pp.12-14, 2002.

[10] R. Garrison, and N. Vaughan, Blended Learning in Higher Education: Framework, Principles, and Guidelines. San Francisco: Jossey-Bass, 2008.

[11] R. Graham, and D. Dziuban, C.D. Core research and issues related to blended learning environments, Handbook of research on educational communications and technology, 3rd ed., J. Spector, M.Merrill, J.Van Merrienboer, and M.Driscoll, Ed., Mahwah, NJ: Lawrence Earlbaum Associates, 2003.

[12] J. Lei, "Quantity versus quality: a new approach to examine the relationship between technology use and student outcomes", British Journal of Educational Technology, vol.41, no.3, pp.455-472, 2010.

[13] H. Lim, and L. Morris, "Learner and instructional factors influencing learning outcomes within a blended learning environment". Educational Technology \& Society, vol.12, no.4, pp.282-293, 2009.

[14] R., Garrison, and N. Vaughan, Blended learning in higher education: Framework, principles, and guidelines, San Francisco: Jossey-Bass, 2007.

[15] C. Dziuban, J. Hartman, and P.Moskal, "Blended learning", EDUCAUSE Center for Applied Research Research Bulletin, 2004.

[16] E. Maloney, "What Web 2.0 can teach us about learning", Chronicle of Higher Education, vol.25, no.18, pp.26, 2007.

[17] T. O'Reilly, "What is Web 2.0: Design Patterns and Business Models for the Next Generation of Software", International Journal of Digital Economics., no.65, pp.17-37, 2007.

[18] K. Laudon, and J.Laudon, "Telecommunications, the Internet, and Wireless Technology," in Management information systems: Managing the digital firm, 12th ed., Upper Saddle River, N.J.: Prentice Hall, 2012.

[19] R. Aucoin, "A Study of Students' Perceptions of the Use of Web 2.0 Applications in Higher Education," M.S. thesis, Univ. British Columbia, Vancouver, Canada, 2014.

[20] M. Bernard, C. Abrami, E. Borokhovski, A. Wade, M.Tamim, A. Surkes and C. Bethel, "A meta-analysis of three types of interaction treatments in distance education", Review of Educational Research, vol.79,no.3 pp.1243-1289,2009.

[21] D. Schunk, P. Pintrich, and J. Meece, "Motivation in education: Theory, research, and applications," 3rd ed., Upper Saddle River, NJ: Merrill Prentice Hall, 2008.

[22] L. Rodgers and J. Withrow-Thorton, "The effect of instructional media on learner motivation", International Journal of Instructional Media, vol.32, no.4 pp.333-340, 2005.

[23] A. Ocak, and M. Akçayır, "Do motivational tactics work in blended learning environments? The ARCS model approach", International Journal of Social Sciences \& Education.vol.3, no.4, pp.1058-1070, 2013.

[24] C. Walker, A. Barbara and A. Robert, "Identification with academics, intrinsic/extrinsic motivation, and self-efficacy as predictors of cognitive engagement", Learning and Individual Differences, vol. 16, pp. 1-12, 2006.

[25] M. Keller, Use of the ARCS model of motivation in teacher training, ERIC, ED 288520, 1983.

[26] S. Green, "Using an expectancy-value approach to examine teachers' motivational strategies", Teaching and Teacher Education, vol.18, no.8, pp. $989-1005,2002$.

[27] B. Huett, K. Kalinowski, L. Moller, and C. Hutt, "Improving the motivation and Retention of Online Students Through the Use of ARCSbased E-mails", Journal of Distance Education, vol. 22, pp. 159-176, 2008.

[28] U. Sekaran, and R. Bougie, Research Methods for Business: A Skill Building Approach, Haddington: John Wiley \& Sons, 2010.

[29] R. Michelle, "Web 2.0 Use In Higher Education", European Journal of Open, Distance and e-Learning, vol. 17, no. 2, pp.130-142, 2014.

[30] N. Loorbach, O. Peters, J. Karreman, and M. Steehouder, "Validation of the Instructional Materials Motivation Survey (IMMS) in a SelfDirected Instructional Setting Aimed at Working with Technology", Instructional Setting British Journal of Educational Technology, vol.46, no. 1 ,pp.204-218,2015. 